\title{
Should we Take into Account only the Synergy of Action by Combining the New Therapeutics against Diabetes?
}

\author{
Belazzouz Abderrahmen Youssouf* \\ Internal Medicine Department, Sisters Bedj Hospital, Algeria
}

Submission: July 30, 2019; Published: August 14, 2019

*Corresponding author: Belazzouz Abderrahmen Youssouf, Internal Medicine Department, Sisters Bedj Hospital, City 42 log N37 Chettia Chlef, Algeria

Abstract

The contemporary drug prescription of new therapeutics in all fields including Diabetes is based on two principles: efficacy and both cardiovascular and renal safety. By analyzing the latest major studies in Diabetology we note that they are focused on these two principles but to our knowledge further studies are necessary to allow a free prescription of different combinations based on the synergy of therapeutic classes. The obligation to go towards these studies comes from the fact that the mechanism of action of the new therapeutic weapons is not so far well elucidated.

Keywords: Diabetes; New therapeutics; Safety; Synergy; Pancreas; Adipose tissue; Liver; Kidneys; Intestine; Renal level; Anti diabetic drugs; Sulfonylurea; Low hypoglycemic; Linagliptin; Glimepiride

\section{Introduction}

Diabetes has long been known to affect the majority of the body's organs, but it is also the result of a dysfunction of several glands such as: pancreas, adipose tissue, liver, kidneys and intestine.

In recent years we are witnessing an advent and a supply by new molecules in diabetology, this is the result of a better knowledge of the physiopathological mechanisms of type 2 diabetes, implying a insulin resistance often mixed (major hepatic and adipose tissue) and a late progressive decline of pancreatic function, but also significant caloric intakes and a massive reabsorption of glucose at the renal level.

Since the appearance of the first oral anti diabetic drugs, the prescription was based on the synergy between those stimulating insulin secretion (Sulfonylurea) and insulin sensitizers (Metformin)

Nevertheless, after having conducted studies proving the cardiovascular safety of each of them and their association, the task was easy as soon as the majority of the patients are on metformin and because of its low hypoglycemic risk in association with the Sulfonylurea.
Several studies have focused on the non-inferiority of these new therapies against Diabetes compared to Sulfonylurea such as: inhibitors of sodium-glucose cotransporter 2 (SGLT2 inhibitors) CAROLINA (Cardiovascular Outcome Study of Linagliptin Versus Glimepiride in Patients with Type 2 Diabetes) [1].

Others have been interested in their cardiovascular safety without comparing to previous molecules such as: EMPA-REG outcome (Empaglifozin 10-25mg) [2], CANVAS (Canaglifozin 100-300mg) [3].

If some studies have proven cardiovascular safety of some SGLT2 inhibitors with Sulfonylurea [4] also in association with insulin [5]. To our knowledge, no study has been interested in the new molecules in associations with each other.

And it is clear that the fact of proving the safety of two molecules separately makes it impossible to conclude with the safety of their combination.

The next years must prove the safety of the combinations either by investing in the pharmacological field in order to 


\section{Current Research in Diabetes \& Obesity Journal}

recognize the mechanisms of exact action of these molecules or failing to carry out large studies concerning patients under combinations of the new therapeutics.

\section{Conclusion}

The current therapeutic array used to heal Diabetes certainly has the advantage of multiple sites of action via targets sitting on different organs; nevertheless, the cardiovascular risk of associations especially with sulfonamides requires study benefits in order to determine the cardiovascular safety of patients. Combinations as well as recently published studies regarding the efficacy of each molecule remain insufficient. Certainly, the therapeutic combinations prescribed in a thoughtful way will be more effective nevertheless the safety of use require either interventional studies or detailed knowledge of the mechanisms of action of the various drugs especially at the cardiac and renal level.

\section{References}

1. Marx N, Rosenstock J, Kahn SE, Zinman B, Kastelein JJ, et al (2015) Design and baseline characteristics of the CARdiovascular Outcome Trial of LINAgliptin Versus Glimepiride in Type 2 Diabetes (CAROLINA®). Diab Vasc Dis Res 12(3): 164-174.

2. Zinman B, Wanner C, Lachin JM, Fitchett D, Bluhmki E, et al. (2015) Empagliflozin, Cardiovascular Outcomes, and Mortality in Type 2 Diabetes. N Engl J Med 373(22): 2117-2128.

3. Mahaffey KW, Neal B, Perkovic V, de Zeeuw D, Fulcher G (2018) Canagliflozin for Primary and Secondary Prevention of Cardiovascular Events: Results From the CANVAS Program (Canagliflozin Cardiovascular Assessment Study). Circulation 137(4): 323-334.

4. Fulcher G, Matthews DR, Perkovic V, de Zeeuw D, Mahaffey KW, et al. (2015) Efficacy and Safety of Canagliflozin Used in Conjunction with Sulfonylurea in Patients with Type 2 Diabetes Mellitus: A Randomized, Controlled Trial. Diabetes Ther 6(3): 289-302.

5. Neal B, Perkovic V, de Zeeuw D, Mahaffey KW, Fulcher G, et al. (2015) Efficacy and safety of canagliflozin, an inhibitor of sodium-glucose cotransporter 2, when used in conjunction with insulin therapy in patients with type 2 diabetes. Diabetes Care 38(3): 403-411.

\begin{tabular}{|l|}
\hline \multicolumn{1}{|c|}{ Your next submission with Juniper Publishers } \\
will reach you the below assets \\
- Quality Editorial service \\
- Swift Peer Review \\
- Reprints availability \\
- E-prints Service \\
- Manuscript Podcast for convenient understanding \\
- Global attainment for your research \\
- Manuscript accessibility in different formats \\
( Pdf, E-pub, Full Text, Audio) \\
- Unceasing customer service \\
Track the below URL for one-step submission \\
https://juniperpublishers.com/online-submission.php \\
\hline
\end{tabular}

